\title{
THE EFFECT OF LIPOPOLYSACCHARIDE ON INTERLEUKIN-1A PRODUCTION BY PERIPHERAL BLOOD LEUKOCYTES IN VITRO AT VARIABLE TIMES AND TEMPERATURES.
}

\author{
Ayaid, K.Zgair \\ College of Science, University of Baghdad, Department of Biology.
}

\begin{abstract}
The concentration of Interleukin-1 $\alpha$ (IL-1 $\alpha$ ) was measured in peripheral blood leukocytes (PBLs) culture at variable times $(0,20 \mathrm{~h}, 23 \mathrm{~h}, 43 \mathrm{~h}$, and $45 \mathrm{~h})$ in presence or absence of lipopolysaccharide (LPS) at variable temperatures $\left(35^{\circ} \mathrm{C}, 37^{\circ} \mathrm{C}\right.$ and $\left.40^{\circ} \mathrm{C}\right)$. There was not high difference in IL- $1 \alpha$ concentrations at $35^{\circ} \mathrm{C}$ and $40^{\circ} \mathrm{C}$ in compared with control group $\left(37^{\circ} \mathrm{C}\right)$ and the same results were found in cultures that supplemented with LPS .There was a slight elevated (Non significant elevated) in IL- $1 \alpha$ concentrations at $35^{\circ} \mathrm{C}+$ LPS after $45 \mathrm{~h}$ and slight decrease at $40^{\circ} \mathrm{C}+\mathrm{LPS}$ after $43 \mathrm{~h}$ in compared with control $\left(37^{\circ} \mathrm{C}+\mathrm{LPS}\right)$, while significant increases were found in cultures supplemented with LPS at variable times and at variable temperatures in compared with opposites temperatures and times with cultures that did not supplement with LPS.
\end{abstract}

\section{Introduction}

Interleukins-1 are classical multifunctional cytokines ,they are produced by macrophage, other antigen presenting cells(APCs ), most of somatic cells, T-cell and activated $B$ cell that products Immunoglobulin .Interleukins-1 activates phagocyte and promotes of hematopoiesis $(1,2)$. The IL-1 family comprises IL- $1 \alpha$ and IL-1 $\beta$ as well as the IL-1 receptor antagonist (IL-1Ra), two types of IL-1 receptors have been identified in human. Although IL-1 $\alpha$ and IL-1 $\beta$ share little homology in primary sequence the two cytokines exert their against effects through binding to the same type I receptor ( IL-1 RI), type II receptor ( IL-1 RII) also binds IL-1 but does not transducer signal $(1,3)$. The receptor antagonist ( IL-1 Ra) binds to IL-1 RI with an affinity comparable to that of IL- $1 \alpha$ and IL-1 $\beta$, but does not elicit biological responses $(4,5)$, Furthermore , intracellular fragments of both receptor types ( IL-1 RI and IL-1 RII) circulate in the blood and function as natural scavengers by binding and neutralizing IL-1 $\alpha$, IL- $1 \beta$ or IL- $1 \mathrm{Ra}$ (6) . The complex array of interacting factor could find modulate IL- $1 \alpha$ responses in vitro (7) .Lipopolysaccharide (LPS) recognition by higher animals involves soluble protein (LPS- binding protein [ LBP] and soluble $\left.\mathrm{CD}_{14}\left[\mathrm{SCD}_{14}\right]\right)(8)$. Membrane receptors $\left(\mathrm{CD}_{14}\right.$ and Toll - like receptor 4 (TLR4) (8). LBP promotes rapid binding of purified LPS from aggregates to membrane - bound $\mathrm{CD}_{14}$ $\left(\mathrm{mCD}_{14}\right)$ on cells or to SCD14 in plasma (9). $\mathrm{CD}_{14}$ is important for conferring sensitive cellular responses to LPS and TLR4 appears to be the most important LPS signal transducer $(10,11)$. Bacterial LPS can activates a variety of mammalian cell types ( part of them PBPLs) and is a powerful activator of the innate immune system, LPS stimulates the synthesis and release of proinflammatory cytokines such as IL_1 from monocytes and macrophages, these cytokines can further activate monocytes , neutrophils and lymphocytes , initiating cellular injury and tissue damage $(12,13)$ .LPS produces fever after 60- 90 minutes that occur after stimulation of IL-1 production from APCs and this carries by the blood stream to the thermoregulatory center in the hypothalamus where physiologic responses are initiated that result in fever and this phenomenon (fever) play an important role in the first step of immune response, so some beneficial effects of fever on the control of infection in a few instances for example antibody production and $\mathrm{T}$-cells proliferation are more efficient at high body temperature $(14,15,16)$. There is proof that IL- $1 \alpha$ can modulate LPS activity and its effect in human body $(17,18)$. The aim of this study was conducted to evaluate the effect of LPS and temperature alone or together on IL- $1 \alpha$ production. 


\section{Material and methods:}

1- Preparation of human peripheral blood leukocytes (PBLs): Peripheral blood buffy coats from healthy donors (five donors) were centrifuged at $2000 \mathrm{rpm}(500 \mathrm{x} \mathrm{g})$ for 5 min. Erythrocytes in the pellet were lysed in sterile $0.83 \% \mathrm{NH} 4 \mathrm{Cl}$ solution for $3 \mathrm{~min}$. at room temperature and PBLs were washed twice by centrifugation ( $500 \mathrm{x} \mathrm{g}$ for $5 \mathrm{~min}$.) in phosphate buffered saline (PBS : $137 \mathrm{mM} \mathrm{NaCl} \mathrm{,} 10 \mathrm{mM}$ $\mathrm{Na} 2 \mathrm{HPO} 4,2.7 \mathrm{mM} \mathrm{KCl}$ and $1.8 \mathrm{mM}$ KH2Po4 [ PH : 7.23\}) (19). The viability of PBLs was measured by trypan blue dye exclusion test (20) and number of PBLs was adjusted to $10^{6}$ viable cells $/ \mathrm{ml}$ with culture medium.

2- Preparation of culture medium: The medium that used was RPMI 1640 (Sigma) supplemented with $10 \%$ fetal bovine serum, $20 \mathrm{mM}$ HEPES and $2 \mathrm{mM}$ L- glutamine.

3- Treatment of cells : Every donor PBLs solution divided into many test tubes ( sterile) and these test tubes divided into two groups. Group A, and group B first group supplemented with $1 \mu / \mathrm{ml}$ of LPS ( O 127 : Bs Difco, Betroit Mich.) and group B did not supplemented with LPS . Every group divided into three subgroup of tubes. The first subgroups incubated at $35{ }^{\circ} \mathrm{C}$, second subgroups incubated at 37 ${ }^{\circ} \mathrm{C}$ and third subgroups incubated at $40^{\circ} \mathrm{C}$ (each tube was contained $1 \mathrm{ml}$ of medium that containing $10^{6}$ PBLs) after that the supernatants were collected from all tubes by centrifugation at $500 \mathrm{x} \mathrm{g} / 10 \mathrm{~min}$. after(Zero time , 20 h., 23 h., 43h., and 45 h.), the supernatants were stored at -20 in microcenrifuge tubes.

4- Detection of IL-1 $\alpha$ : IL-1 $\alpha$ level was measured by using human cytokine immunoassay kit (Bachman coulter, Marseille Cedex 9, France) according to the manufacturer's protocol.

5- Statistical analysis: $t$ - test was performed.

\section{Results and discussion}

The concentrations of IL- $1 \alpha$ were detected in cultures of PBLs, slight significant increase was found in this concentration at $35{ }^{\circ} \mathrm{C}$ but at $23,43 \mathrm{~h}$ and 45h in compared with (control) for all times .At $40^{\circ} \mathrm{C}$ slight decreases were found in the concentrations of IL- $1 \alpha$ at $43 \mathrm{~h}$ and $45 \mathrm{~h}$ only when compared these results with control $\left(37^{\circ} \mathrm{C}\right.$ for all times) Table (1) .

Table (1)

The concentration of $I L-1 \alpha \mathrm{pg} / \mathrm{ml}$ at variable times and at variable temperatures

\begin{tabular}{|c|c|c|c|c|}
\hline Temperatures & $20 \mathrm{~h}$ & $23 \mathrm{~h}$ & $43 \mathrm{~h}$ & $45 \mathrm{~h}$ \\
\hline $35^{\circ} \mathrm{C}$ & $\begin{array}{c}128.7 \\
\pm 8.5 \\
\text { NS }\end{array}$ & $\begin{array}{c}159 \\
\pm 9.5 \\
P<0.05\end{array}$ & $\begin{array}{c}130 \\
\pm 7.9 \\
\mathrm{P}<0.05\end{array}$ & $\begin{array}{c}125 \\
\pm 10.4 \\
P<0.05\end{array}$ \\
\hline $\begin{array}{c}37^{\circ} \mathrm{C} \\
\text { control }\end{array}$ & $\begin{array}{r}130 \\
\pm 7.6 \\
\end{array}$ & $\begin{array}{c}140 \\
\pm 8.3\end{array}$ & $\begin{array}{c}104 \\
\pm 10.1 \\
\end{array}$ & $\begin{array}{r}110 \\
\pm 9.7 \\
\end{array}$ \\
\hline $40^{\circ} \mathrm{C}$ & $\begin{array}{c}139 \\
\pm 12 \\
4 \\
\mathrm{NS}\end{array}$ & $\begin{array}{c}130 \\
\pm 11.9 \\
\mathrm{NS}\end{array}$ & $\begin{array}{c}88 \\
\pm 9.6 \\
\mathrm{P}<0.05\end{array}$ & $\begin{array}{c}93 \\
\pm 10.1 \\
\mathrm{P}<0.05\end{array}$ \\
\hline
\end{tabular}

In compared the concentrations of IL- $1 \alpha$ in $\left(35^{\circ} \mathrm{C}+\mathrm{LPS}\right.$ and $\left.40^{\circ} \mathrm{C}+\mathrm{LPS}\right)$ with control $\left(37^{\circ} \mathrm{C}+\mathrm{LPS}\right)$ the slight different was found .There is little increase in concentration of IL- $1 \alpha$ at ( $\left.35^{\circ} \mathrm{C}+\mathrm{LPS}\right)$ at $45 \mathrm{~h}$ only, and decrease in concentration of IL- $1 \alpha$ at $(40+\mathrm{LPS})$ at $43 \mathrm{~h}$ and $45 \mathrm{~h}$ when compared with control $\left(37^{\circ} \mathrm{C}+\mathrm{LPS}\right)$ Table (2) .

Table (2)

The concentration of $\mathrm{IL}-1 \alpha \mathrm{pg} / \mathrm{ml}$ at variable times and at variable temperatures in vitro in presence of LPS.

\begin{tabular}{|c|c|c|c|c|}
\hline Temperatures & $\begin{array}{l}\text { after } \\
20 \mathrm{~h}\end{array}$ & $\begin{array}{l}\text { after } \\
23 \mathrm{~h}\end{array}$ & $\begin{array}{l}\text { after } \\
43 \mathrm{~h}\end{array}$ & $\begin{array}{l}\text { after } \\
45 \mathrm{~h}\end{array}$ \\
\hline $35^{\circ} \mathrm{C}+$ LPS & $\begin{array}{c}251 \\
\pm \\
15.5 \\
\mathrm{NS} \\
\end{array}$ & $\begin{array}{c}286 \\
\pm \\
14.1 \\
\text { NS }\end{array}$ & $\begin{array}{c}220 \\
\pm 16.2 \\
\mathrm{NS}\end{array}$ & $\begin{array}{c}230 \\
\pm 13.4 \\
\mathrm{P}<0.05\end{array}$ \\
\hline $\begin{array}{c}37^{\circ} \mathrm{C}+\mathrm{LPS} \\
\text { ( control) }\end{array}$ & $\begin{array}{c}260 \\
\pm \\
19.7\end{array}$ & $\begin{array}{c}271 \\
\pm \\
18.3\end{array}$ & $\begin{array}{c}230 \\
\pm 15.9\end{array}$ & $\begin{array}{c}210 \\
\pm 17.8\end{array}$ \\
\hline $40^{\circ} \mathrm{C}+\mathrm{LPS}$ & $\begin{array}{c}268 \\
\pm \\
17.1 \\
\mathrm{NS} \\
\end{array}$ & $\begin{array}{c}258 \\
\pm \\
18.2 \\
\mathrm{NS} \\
\end{array}$ & $\begin{array}{c}204 \\
\pm 20.2 \\
p<0.05\end{array}$ & $\begin{array}{c}188 \\
\pm 19.4 \\
\mathrm{P}<0.05\end{array}$ \\
\hline
\end{tabular}

When compared the concentration of IL- $1 \alpha$ between presence and absence of LPS in all temperatures for all times. The concentrations of IL- $1 \alpha$ in presence of LPS were higher than the concentration of IL- $1 \alpha$ in absence of LPS in every temperatures and all times Figure (1). 

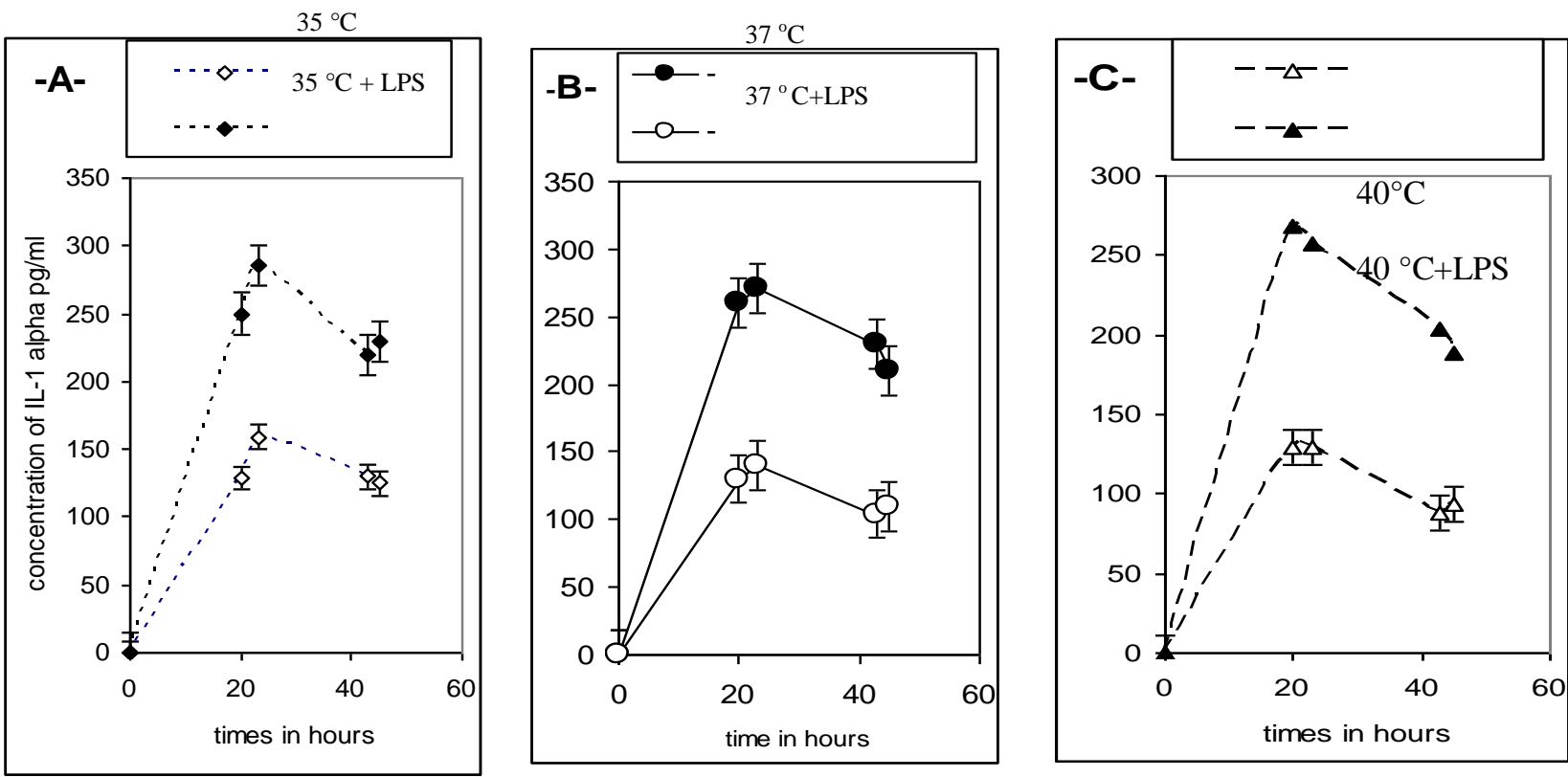

Figure -1- Comparison of concentrations of IL-1 $\alpha$ in presence and absence of LPS in many temperatures: 1- (A) $35^{\circ} \mathrm{C}, 2-$ (B) $37^{\circ} \mathrm{C}$ and 3- (C) $40^{\circ} \mathrm{C}$

LPS potently stimulates the production of IL-1 and which has a large number of biological activities, thus activates of LPS are believed to be mostly mediated by IL-1 or cytokine network involving IL-1 $(2,21$, $22)$. Other investigators stimulated cells to produce IL-1 in vitro; they found significant increase in IL-1 production at 3 and $20 \mathrm{~h}$ of incubation (23), these results that obtained by last investigator sometimes agree with our results. We documented LPS could stimulate PBLs to production of IL- $1 \alpha$ at every temperatures more than cultures that were not supplemented with LPS. LPS play an important role in activation of normal cells to produce IL-1 and other types of cytokines by binding (LPS) with special receptors on these cells. This binding will reach activated signal to the NFK B and this will activate special gene that responsible for production of IL-1 and other proinflammatory cytokines thus LPS has high ability to produce inflammation in human body and animals (8).

IL-1 produces by many types of normal cells besides PBLs such as fibroblast, endothelial cells epithelial cells and other types of cells $(2,24)$. Besides normal cells tumor cells can produce IL-1 and last play a crucial role in regulation of immune system against tumor in special places (25). IL-1 may produces after stimulation with foreign stimulator or by self stimulator such as other cytokines or produce by autocrine stimulation (cytokine stimulates its cell to produce the same cytokine) (26), variable temperatures have ability to stimulate of immune system (14, $15)$. But we did not find any evidence of the effect of temperatures on IL-1 production. but Interleukines- 1 are an important inducer of numbers of effects that are mediated through hypothalamus, they are endogenous pyrogens ( they induce fever) (1) that is meaning IL-1 elevates temperature but the last do not affect on IL-1 and we suggest there is not any synergistic effects between temperatures and LPS on IL-1 production by peripheral blood leukocytes in vitro.

\section{References}

[1] Oppenheium, J. J. and Ruscetti, F. W., "Cytokines".In:"Medical mmunology", eds Parslow, T.G., Stites, D.P., Terr, A.I. and Imboden, J.B. $10^{\text {th }}$ edition, McGraw-Hill, New York, USA, 2000, pp. $148-166$.

[2] Dinarello, C.A.,"Biological basis for Interleukine-1 in disease", Blood, Vol. 87, 1996, pp.2095-2147.

[3] Sims, J.E., Gayle, M.A.and Slack, J.L.,"Interleukin-1 signaling occurs exclusively via the type I receptor", 
Proc. Natl. Acad. Sci. USA, Vol. 90, 1993, pp.6155 - 6159 .

[4] Arend,W.P. and Dayer,J.M. "Cytokines and cytokines inhibitors or antagonists in rheumatoid arthritis" , Arthritis Rheum, Vol. 33, 1990, pp. 305 - 315.

[5] Hannum,C.H. and Wilcox,C.J., Arend , W.P.,"Interleukin-1 receptor antagonist activity of a human interleukin-1 inhibitor", Nature, Vol. 343, 1990 ,pp. 336 - 340.

[6] Arend, W.P., Malyak, M.and Smith, M.F.," Binding of IL- $1 \alpha$, IL- $1 \beta$ and IL1 receptor antagonist by soluble IL-1 receptor and level of soluble IL-1 receptors in synovial fluid ", $\mathrm{J}$. Immunol., Vol.153, 1994, pp. 4766 4774.

[7] Burger,D., Chicheportiche, R.and Giri , J.G.," The inhibitory activity of human interleukin-1 receptor antagonist is enhanced by type II interleukin-1 receptor and hindered by interleukin-1 soluble receptor", J. Clin. Inves., Vol. 96, 1995 ,pp.38 - 41.

[8] Parslow,T.G. and Bainton, D.F.," Innate immunite", In: "Medical Microbiology", eds: Parslow, T.G., Stites, D.P., Terr, A.I. and Imboden, J.B. $10^{\text {th }}$ edition , McGraw-Hill, New York, USA, 2001, pp. 19 -39.

[9] Hailman, E., Lichenstein,H.S., Wurfel, M.M., Miller,D.S., Johanski,D.A., Kelley,M., Busse,L.A., Zukowski,M.M. and Wright,S.D., "Lipopolysaccharide (LPS)-binding protein accelerates the binding of LPS to CD14", J.Exp.Med. , Vol.179, 1994, pp.269 - 77.

[10] Haziot, A., Ferrero,E., Kontgen,F., Hijiya,N., Yamamoto,S., Silver,J., Stewart, C.L., and Goyert, S. M.,"Resistance to endotoxin shock and reduced dissemination of gram negative bacteria in $\mathrm{CD}_{14}$ - deficient mice", Immunity, Vol. 4, 1997, pp. $407-414$.

[11] Hoshino,K., Takeuchi,O., Kawai,T., Sanjo,H., Ogawa,T., Takeda, Y., Takeda,K. and Akira,S.,"Cutting edege: Toll-Like receptor 4 ( TLR4) deficient mice are hyporesponsive to
Lipopolysaccharide : evidence for TLR4 as the LPS gene product", J. Immunol., Vol.162, 1999,pp. 3749 3752.

[12] Svanborg, C., Godaly,G. and Hedlund, M., "Cytokine responses during mucosal infections : role in disease pathogenesis and host defence", Curr. Opin. Microbiol. , Vol. 2, 1999, pp. 99-104.

[13] Matsukawa, A. and Yoshinaga , M., "Sequential generation of cytokines during the initiative phase of inflammation, with reference to neutrophils", Inflamm. Res., Vol. 47 (Suppl.3), 1998, pp. S 137

[14] Nair, R., "Immunology". In : "Medical Microbiology" ,eds: Brooks ,G. F. , Butel, J. S. and Morse, S. A. , $26^{\text {th }}$ edition , Lang Medical Books, McGow- Hill.New York, USA, 2001, pp. $109-32$.

[15] Books,G. F., Butel, J. S. and Morse, S. A.," Medical Microbiology", $26^{\text {th }}$ edition, Lang Medical Books, McGow-Hill.New York, USA, 2001, pp.133 -144.

[16] Roderick, N., Immunology", In: "Medical Microbiology" ,ed: Brooks, G. F., Butel, J. S. and Morse, S. A., $23^{\text {rd }}$ ed ,New York ,USA, pp.119-145.

[17] DeBond, E.S. J.M., Niemarkt A.E., Tamminga, R. Y. J., Kimpen,J.L.L., Kamps, W. A. and deleij, L.H.M.F., "Lipopolysaccharide -induced cytokine production in peripheral blood mononuclear cells : intracellular of tumor necrosis factor $\alpha$ and interleukin- $1 \beta$ detected with a three color immunofluorescence technique", Histochem. Cell Biol., Vol. 106, 1996, pp. 593- 8 .

[18] Tsujimoto, H., Hasegawa, A., "Molecular cloning of eguine interleukin- $1 \alpha$ and- $\beta$ cDNAs", Vet. Immunol,. Immunopath., Vol. 48, 1995, pp. 221- 231.

[19] Kim, H. Y. and Rikihis, A. Y., "Expression of Interleukin-1 $\beta$, Tumer necrosis factor Alpha and Interleukin-6 in human peripheral blood leukocytes exposed to recombinant major surface 
protein P44", Infections and Immunity, Vol. 68, 2000 pp. 3394-402.

[20] Lefkovits, I and Cosenza, H., "Assay for plaque forming cells", in: "Immunological methods", Eds: Lefkovits, I. et al., Academic press, New York, USA, 1979, pp. $277-85$.

[21] Lynn, W.A., and Golenbock,D.T., "Lipopolysaccharide antagonists", Immunol. Today, Vol. 13, 1992, pp. 271-275.

[22] Watson, R.W.G., Redmond, H.P., and Bouchier-Hayes, D., "Role of endotoxin in mononuclear phagocytes - mediated inflammatory responses", J. Leukoc. Biol., Vol. 56, 1994, pp. 95 $-103$.

[23] Seethanathan,P., Bottoms,G.D. and Schafer ,K., "Characterization of release of tumor necrosis factor ,Interleukin-1 and superoxide anion from equine white blood cells in response to end toxin", Am. J. Vet. Res., Vol. 51, 1990, pp. 1211-1225.

[24] Akira,S., Hirano,T., Taga,T. and Kishimoto,T.,"Biology of multifunctional cytokines :m IL-6 and related molecules (IL-1 and TNF ) ", (Review) FASEB J., 1990, pp. 2860-5.

[25] Kutteh, S., Baker, V. V., and Doellgast, G. J., "Autogous antibodies eluted from membrane fragments in human ovarian epithelial nepoplastic effusion .III.Cytotoxic potential and characteristics of antigen", Am. J. Obstet. Gynecol., Vol. 163, 1990, pp. 1301 -9.

[26] Huleihel, M., Maymon,E., Iura, B.P., Prinsloo, I., Benharroch,D., YanaiInbar,I, and Glezerman, M., "Distinct patterns of expression of Interleukin-1 and by normal and cancerous human ovarian tissue", European Cytokine Network, Vol.8, 1997,pp.179-87.

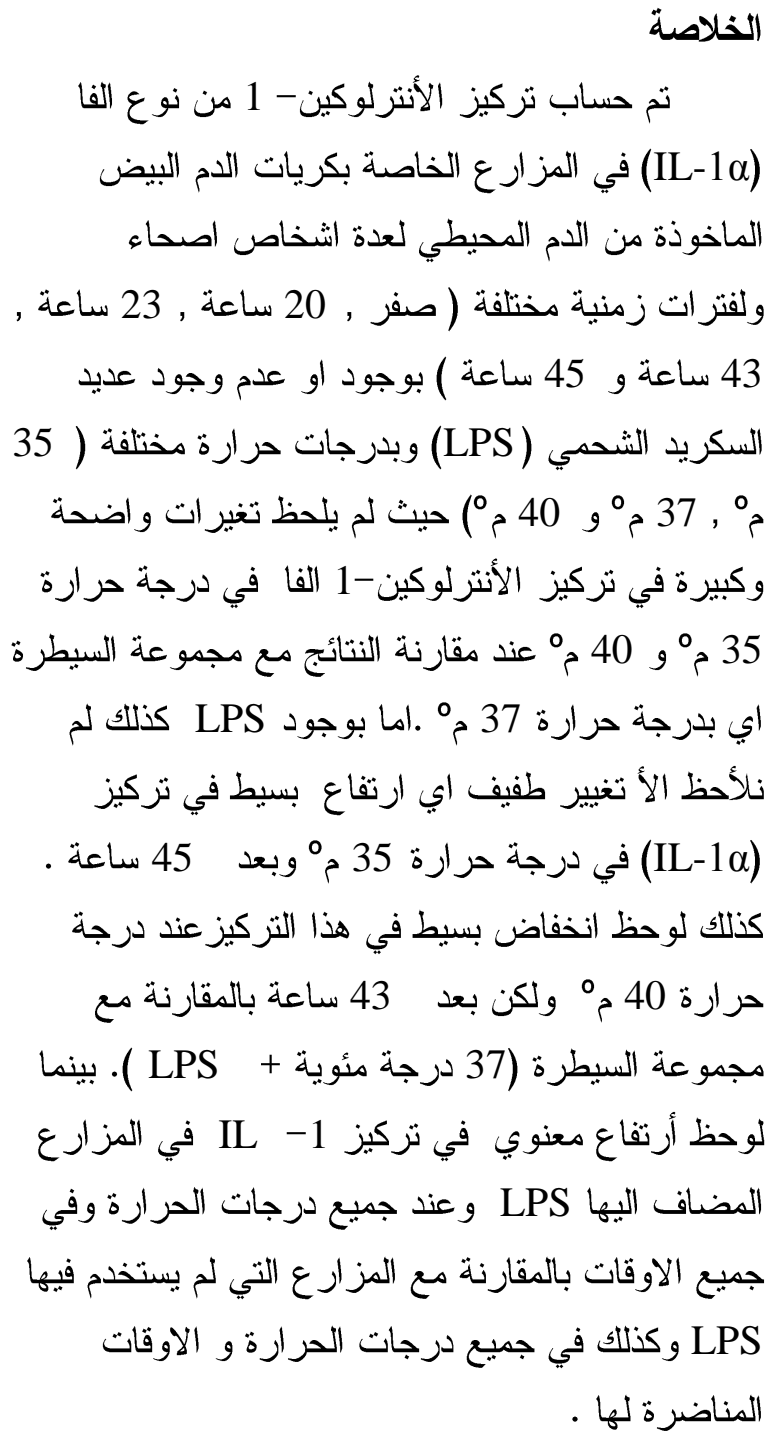

